
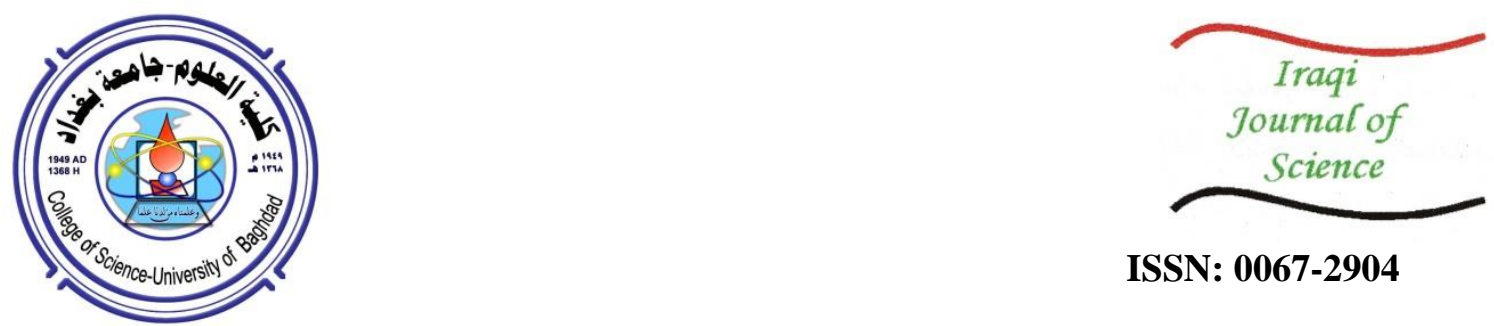

ISSN: 0067-2904

\title{
Association of Serum Urotensin-II Levels with Insulin Resistance and Endothelin-I in Type-II Diabetes Mellitus Patients
}

\author{
Sara M. Khidhir*, Almas MR Mahmud, Ismail M. Maulood \\ Department of Biology, College of Science, University of Salahaddin, Erbil, Iraq
}

Received: 11/11/2020 Accepted: 10/2/2021

\begin{abstract}
Urotensin-II (UII), a pluripotent vasoactive cyclic peptide, exhibits the progression of cardiovascular diseases and the glucose metabolic disorder of insulin resistance. Type 2 Diabetes Mellitus (T2DM) is entirely associated with insulin resistance. This study aimed to demonstrate the association of UII with insulin resistance in diabetic and non-diabetic subjects. A total of 73 male and female subjects aged 40-60 years were recruited in this case-control study. They included 35 non- diabetic subjects with a body mass index of (BMI) $\leq 25$ and 38 patients with Diabetes Mellitus and BMI $\geq 25$. UII levels were assessed beside other vasoactive and clinical parameters. The results revealed that patients with T2DM had elevated UII and Endothelin-I (ET-I) levels, along with positive correlations with the insulin-resistance marker of Homeostatic Model Assessment for Insulin Resistance (HOMA-IR), blood pressure (BP), fasting blood glucose (FBG), hemoglobin A1c ( $\mathrm{HbA1C})$, and asymmetric dimethylarginine (ADMA). Results from stepwise multiple regressions indicated that UII correlated positively with the increases in the levels of serum cholesterol, ET-I, urea, ADMA, and FBG. This study concludes that the increase in UII level has a positive relation with insulin-resistance and the increase in ET-I level. However, UII could inhibit glucose-induced insulin secretion and, hence, can be utilized as a marker for T2DM and its complications through inflammatory microangiopathy.
\end{abstract}

Keywords: Urotensin-II, T2DM, HOMA-IR, ET-I, ADMA.

ارتفاع مستويات اليورؤتينسين مع مقاومة الأنسولين والاندوثلين فى مرضى السكري من النوع الثانى

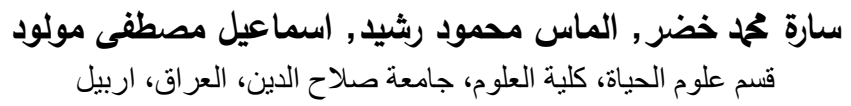

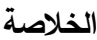

يعد يورؤتينسين ببتيد قابض للاوعية ذو قابلية انقباضية مضاعفة عن ببتيد الاندوثلين ويعد المحرك

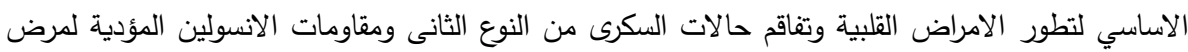

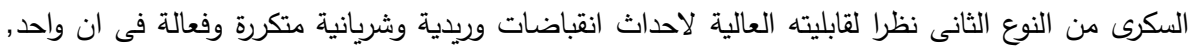

الامر الذى دفعنا الى دراسة العلاقة الترابطية بين يورؤتينسين ومقاومة الانسولين من جهة وبين يورؤتينسين

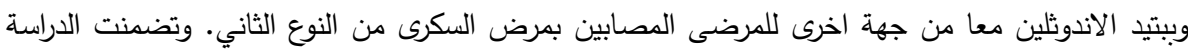

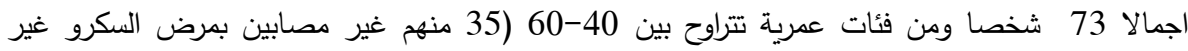

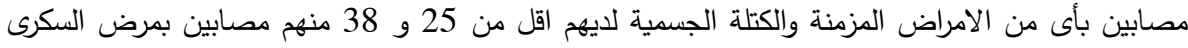

*Email: sara.khidhir@su.edu.krd 


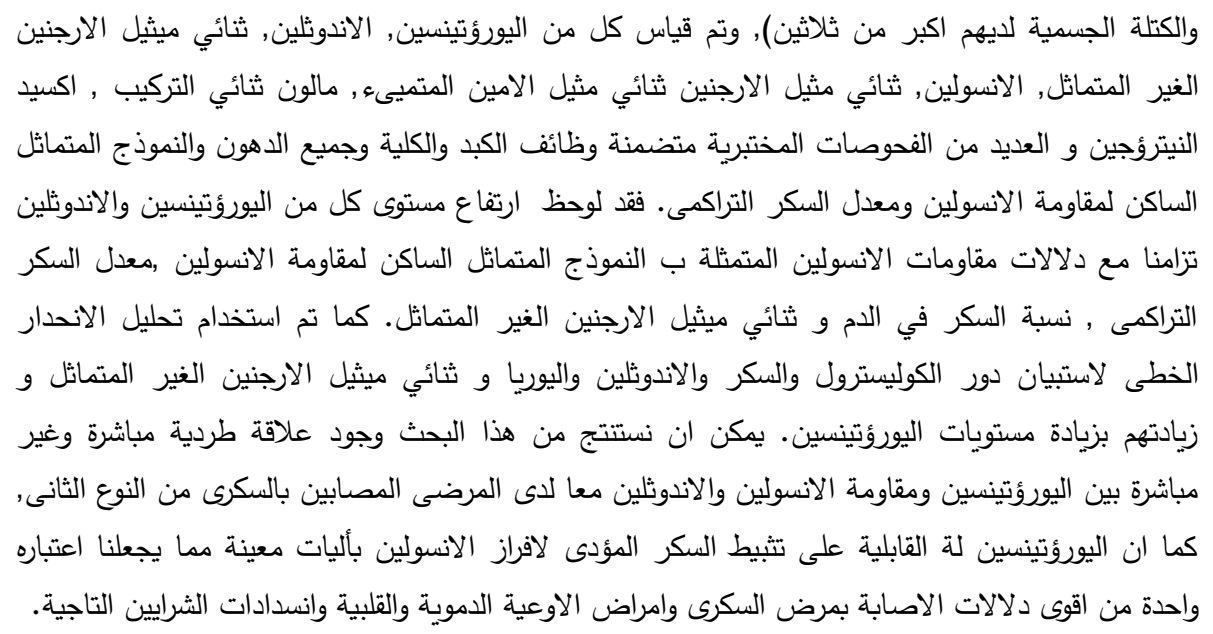

\section{Introduction}

Diabetes mellitus type 2 is a glucose metabolism dysfunction associated with insulin resistance, with incidence being increased with obesity. It is a world widely distributed disorder, causing a common public health problem with extra complications if remained untreated. Various factors lead to complications and microangiopathy, such as insulin-resistance and vasoactive substances secreted from vasculatures and endothelial cells. These vasoactive substances include strong and long lasting vasoconstrictors, such as endothelin-I and UII [1]. ET-I is a 21 -amino acid peptide, with a potency that is lower than that of UII by 50\%. ET-I, as UII, has a pivotal role in the development of injured endothelium pathogenesis. Its predominant vasoconstriction effect is appeared through the activation of its endothelin A (ETA) and Endothelin B (ETB) receptors through the body organs and vessels [2]. Usually, T2DM is accompanied by hypertriglyceridemia [3], hypercholesterolemia [4], hyperuricemia [5], and hyperhomocysteinemia [6] and hypertension. These effects change the tone and stability of vasculatures, causing a mechanical stress on veins and arteries that are already under oxidative stress load in T2DM [7]. These metabolic disorders are risk factors for cardiovascular diseases (CAD) and easily develop in T2DM, initiating the complications of the cardiovascular system and the progression of coronary artery disease, atherosclerosis, myocardial infarction, and stroke $[8,9]$.

Urotensin-II is the most potent mammalian vasoconstrictor discovered till now, produced and synthesized within endothelial cells of many arteries and venous cell walls. UII has been engaged with diabetes disease and complications through its activity on the peripheral vascular bed [10]. UII is a pluripotent peptide that plays essential roles in the development of insulin-resistance. The signal transduction pathway begins once UII binds to its receptor, which then phosphorylates G-protein Gaq/11 coupled receptor, activating phospholipase C (PLC) pathway and leading to the activation of inositol trisphosphate (IP3) and diacylglycerol (DAG). When activated, IP3 opens L- type calcium channels and, consequently, vasoconstriction occurs through the $\mathrm{Ca}_{2}^{+} /$calmodulin/myosin light chain system [11].

Urotensin-II has direct influences on pancreatic $\beta$-cells by decreasing or inhibiting glucose induced insulin through reducing phosphorylation of insulin-receptor substrate 1 . These influences are also exhibited through the inhibition of insulin response to L-type $\mathrm{Ca}^{+}$channels, increasing phospholipid turnover or activating the adenylate cyclase/cAMP pathway $[12,13]$.

Some studies demonstrated a link between elevated UII levels and FBG, HbA1C, and HOMA-IR levels [14] with complications of T2DM, while other studies showed no significant increase of FBG, HbA1C, BMI, systolic blood pressure (SBP), and diastolic blood pressure (DBP) with the increase of serum UII [15]. Therefore, we aimed to establish the relation of UII levels in diabetic and nondiabetic subjects with insulin resistance and other metabolic and vasoactive parameters, such as ET-I. We also aimed to establish the association between UII, ET-I, and insulin resistance in T2DM.

\section{Materials and methods}

\section{Ethical statement}

This study has been approved by the local ethics committee of Hawler Medical University, Erbil, Iraq (protocol number 2).

Subject characteristics 
This case control study was carried out in the Department of Biology/Salahaddin University, Erbil, Iraq. A total of 73 subjects aged 40-60 years were recruited (35 volunteers without DM with BMI $\leq 25$ and 38 patients with $\mathrm{DM}$ and $\mathrm{BMI} \geq 25$ ). All subjects were free of criteria that may affect the results, such as being smokers, alcoholics, pregnant and/or pregnant, as well as having thyroid disorders and other diseases that may affect our results [16].

Anthropometric evaluations

For subjects with barefoot, weight $(\mathrm{kg})$, age, height $(\mathrm{cm})$, and $\mathrm{BP}(\mathrm{Hg} / \mathrm{mm})$ were assessed, while other physical examinations, including BMI and waist circumference were also performed . Systolic blood pressure (SBP) and diastolic blood pressure (DBP) were measured manually by sphygmomanometer, then mean arterial pressures (MAP) was calculated by MAP $=\mathrm{SBP}+2(\mathrm{DBP}) 3$ $\mathrm{mm} \mathrm{Hg}$, defined as an average BP during one cardiac cycle [17]. Estimated glomerular filtration rate eGFR was calculated by the Modification of Diet in Renal Disease (MDRD) equation for calculating GFR $=175 \times$ standardized $S(c r)(-1.154) \times$ age $(-0.203) \times 1.212$ (if black) x 0.742 (if female), where $\mathrm{S}(\mathrm{cr})$ stands for serum creatinine [18].

Blood sampling

Upon measurements of anthropometrics, $10 \mathrm{ml}$ of pre-prandial blood was collected in Gel and Clot Activator and K2 EDTA tubes and separated at $2000 \mathrm{rpm}$ for 15 minutes. After being clotted, the sera were stored at $-80{ }^{\circ} \mathrm{C}$ prior to analysis. For all participants, various tests, including fasting blood glucose (FBG), total cholesterol, triglycerides (TGs), high density lipoproteins (HDL), low density lipoproteins (LDL), HbA1C, liver function tests (including alanine aminotransferase (ALT), aspartate aminotransferase (AST), and alkaline phosphatase (ALP)), and renal function tests (including creatinine (Cr), urea, and uric acid)) were all assessed by using GESAN CHEM 400 AUTOCHEMISTRY ANALYZER (Gesan production S.R.L./ Italy) which depends on colorimetry and turbidimetry.

Very low density lipoprotein cholesterol (VLDL-C) was measured by Friedewalds equation of TG/5 [19]. Both insulin resistance and insulin sensitivity were calculated using HOMA-IR application and Quantitative Insulin Sensitivity Check Index (QUICKI) formula as follows:

HOMA-IR $=($ fasting insulin $[\mu \mathrm{IU} / \mathrm{mL}] \times$ fasting glucose $[\mathrm{mg} / \mathrm{dL}] / 405)[20]$.

QUICKI $=[1 /(\log$ Insulin $)+\log ($ Glucose $)][21]$.

Circulating serum DDAH, ADMA, insulin, UII, and ET-I were measured individually with distinct and fixed protocols according to the commercial kits from Sunlong biotech Co.,Ltd (Human Dimethylarginine dimethylaminohydrolase DDAH ELIZA Kit, REF NO. SL2823Hu, ; Human Asymetric Dimethylarginine ADMA ELIZA Kit, REF NO. SL0312Hu; Human Insulin ELISA Kit, REF NO. SL0933Hu; Human Urotensin-II, UT-II ELISA Kit, REF NO. SL1951Hu; Human Endothelin 1, ET-1 ELISA Kit, REF NO. SL0651Hu) using semi-automated human Enzyme Linked Immunosorbent Assay (ELISA). Nitric oxide (NO) concentration was indirectly determined via Griess's reaction depending on the measurement of nitrite concentration. Nitrate was reduced to nitrite in the presence of cadmium, then converted to nitric acid. Concentrations were determined by spectrophotometric analysis at $543 \mathrm{~nm}$ and the products were expressed as $\mu$ moles (UNICO spectrophotometer SN SQU10111012002) [22]. Buege and Aust method was adopted to measure serum malondialdehyde (MDA) (UNICO spectrophotometer SN SQU10111012002), based on the reaction between lipid oxidation products with thiobarbituric acid, leading to a colored product [23, 24].

Statistical analysis: the context of normally distributed data was expressed as mean value \pm SEM, while non-normally distributed data were expressed as median or midspread interquartile range (IQR). A p-value lower than 0.05 was considered statistically significant. Unpaired t-test was used to compare between all recruitments by using GraphPad Prism 8 software [25]. Mann-Whitney t-test was used for non-parametric variables. Receiver Operating Characteristic (ROC) curve was applied to compare the sensitivity and specificity of variables in all subjects. Statistical Package for Social Science (IBM SPSS Statistics for Windows, Version 25.0., 2017, Armonk, NY) was applied to analyze the correlation coefficient of UII and all other anthropometrics and clinical parameters. Spearman and Pearson (r) correlation was used. The data log-transformed and stepwise multiple regressions were performed to predict the relationships of UII with other variables. 


\section{Results}

Serum UII in diabetic and non-diabetic subjects

Serum UII level was found to be higher significantly in the diabetes group among both male and female subjects. These results provide important insights into UII as a valuable marker for DM and insulin resistance in both sexes. T-test was used to compare UII in both subject groups, as illustrated in Figure-1.

Biomarkers for identifying risk factors

Risk factors were determined using ROC curves. All indications pointed to UII as a good biochemical and clinical marker for T2DM patients and as a preliminary biomarker for insulin resistance. Furthermore, ET-I, ADMA, DDAH, HOMA-IR, HOMA-IS, HbA1C, NO, MDA, waist circumference, BMI, SBP, DBP, MAP, FBG, and ALT were all found to be excellent markers for T2DM in the entire set of subjects, with their AUC values being nearly equal to 1 (Figure-2).
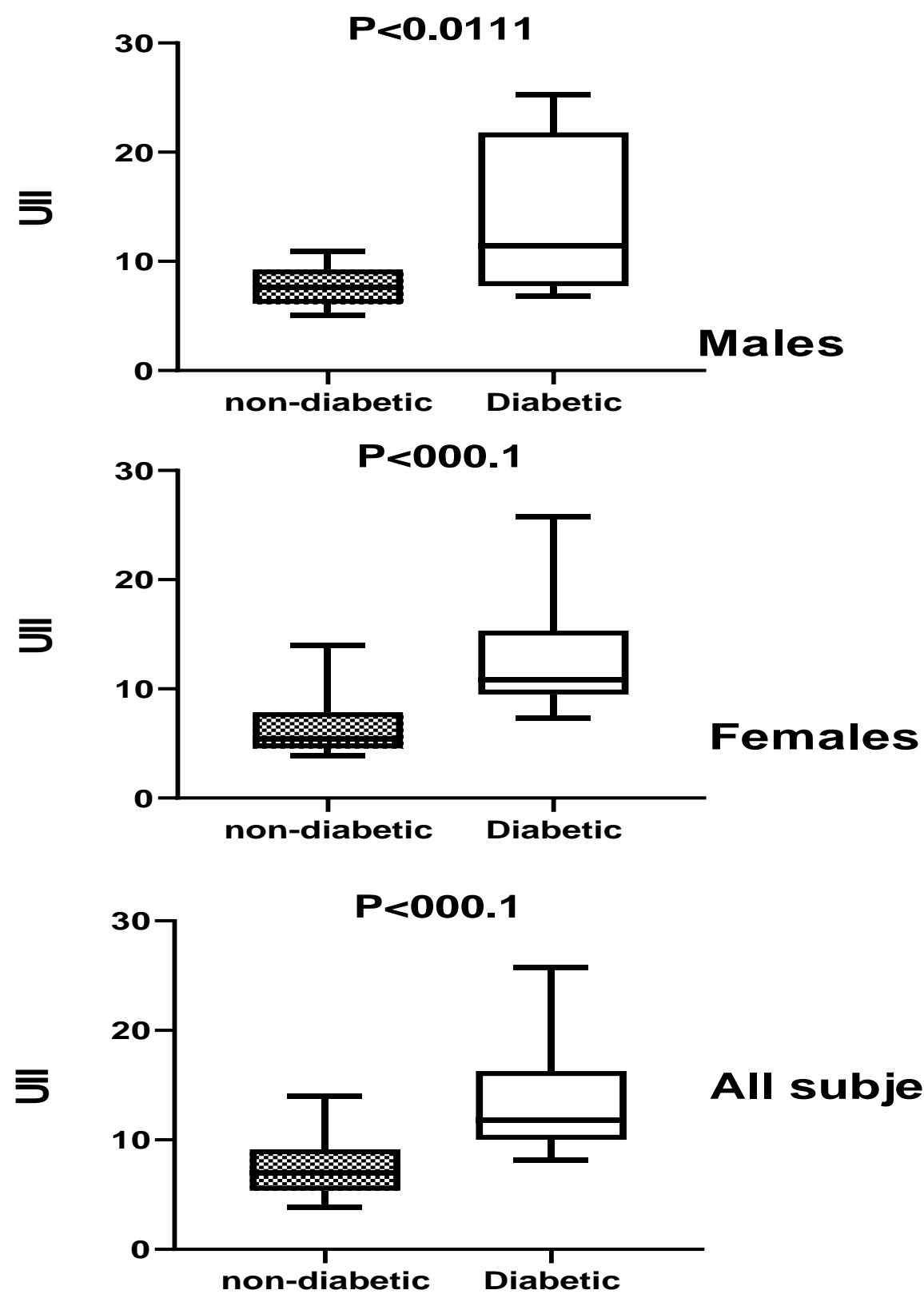

Figure 1-Results of t-test for Urotensin-II levels in both diabetic and control groups for both males and females. 
$\mathrm{HbA1C}$

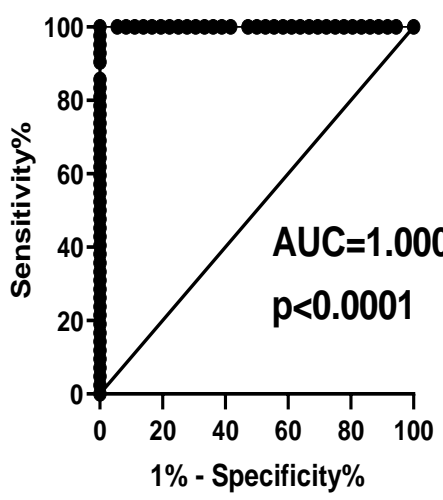

NO

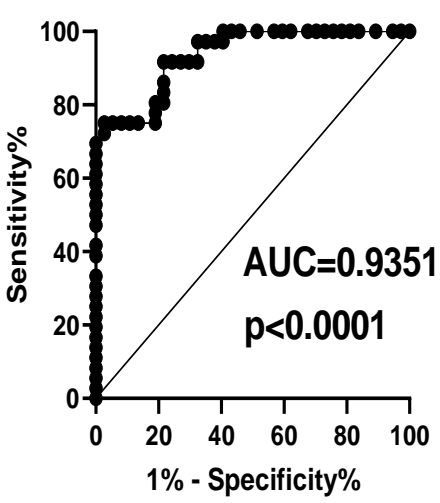

ET-1

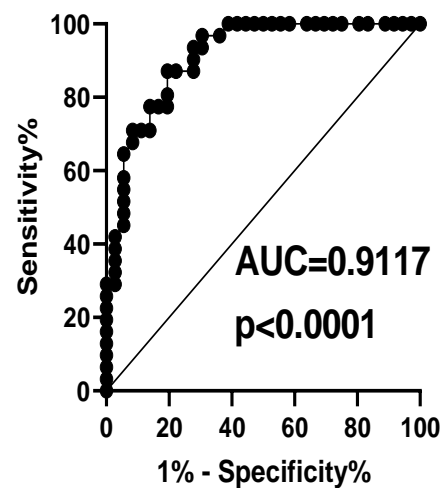

HOMA-IR

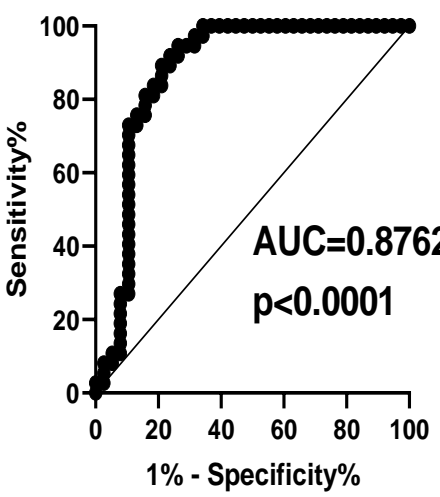

MDA
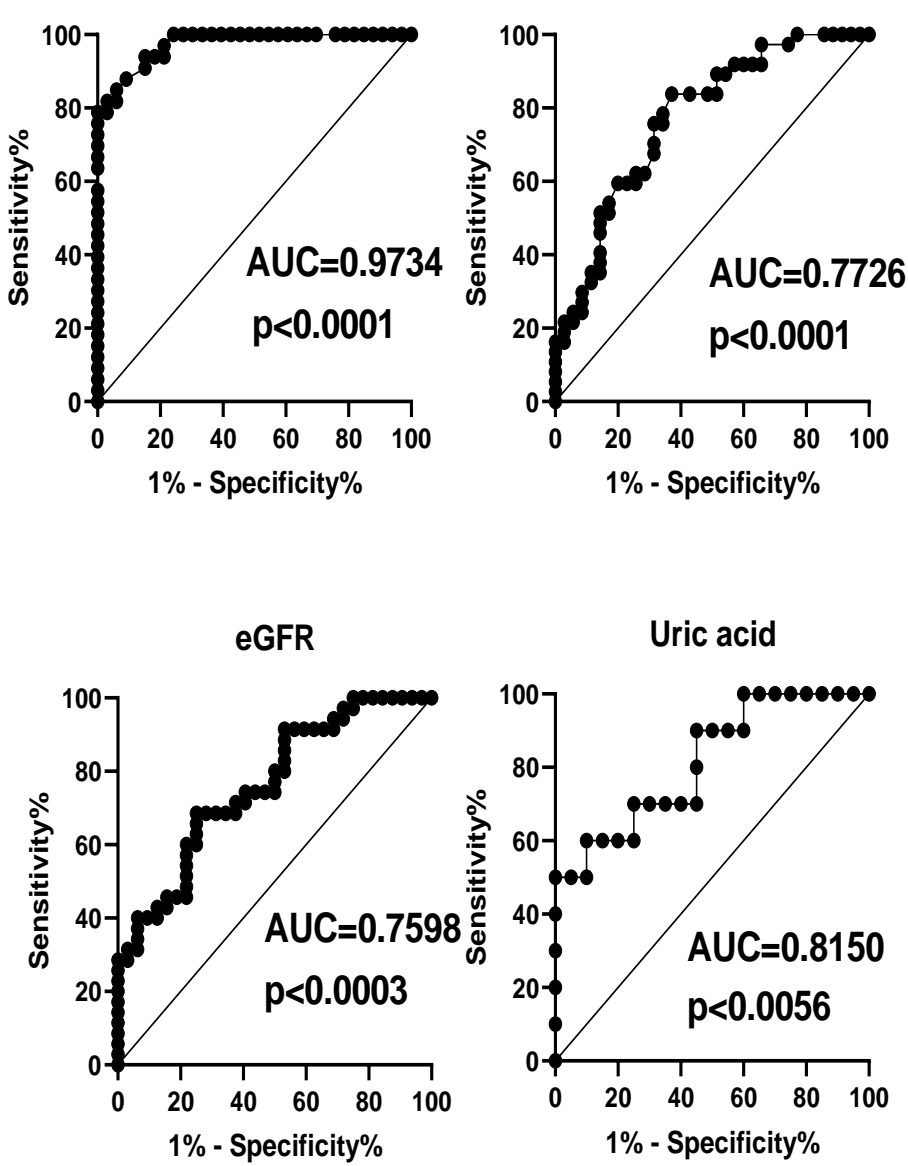

Uric acid

HOMA-IS

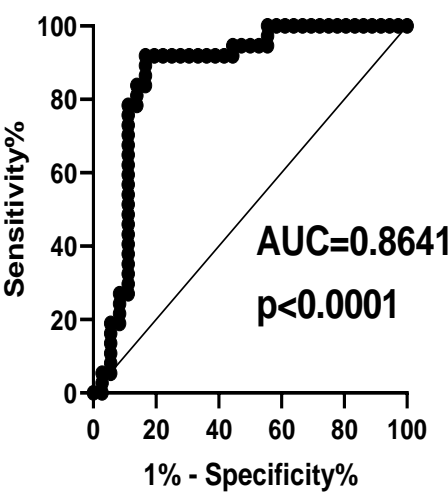

ADMA

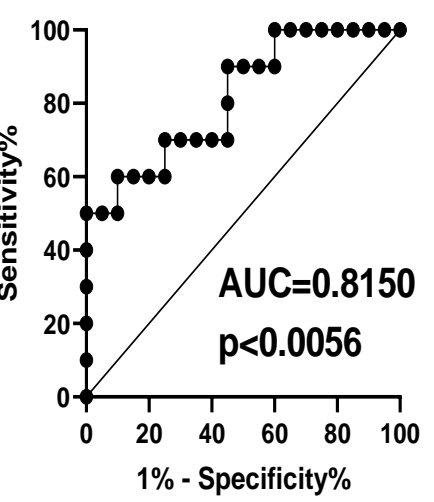

Figure 2-The ROC curves of biomarkers for subjects drawn above related UII in both males and females. $p<0.05$ indicates the statistically significant difference. AUC $=$ area under the curve.

Correlation between serum UII levels and clinical and anthropometric parameters

To evaluate the proper relationship between UII levels and clinical and anthropometric parameters, Pearson's correlation analysis was used. The studied UII levels showed a highly significant and positive correlation with most of studied parameters, except HDL-C, LDL-C, and serum insulin. 
Height, HDL-C, and QUICKI showed negative correlations with UII, as illustrated in Table- 1. The correlation between UII and other metabolic parameters are illustrated in Figure-3.

Multiple regression analysis of serum UII with other parameters

The data showed the presence of independent parameters, such as FBS, Urea, ET-I, and cholesterol, that are proposed to be in a direct relation with UII. For this reason, multivariate linear regression model was used by adding variables one by one to the model, as displayed in Table- 2 . Consecutively, the biochemical and vasoactive variables are added as in Table- 3 .

Table 1- Correlation coefficient results of UII with anthropometrics and metabolic parameters of the studied subjects.

\section{Urotensin-II $\quad(n=73)$}

r p

\begin{tabular}{|c|c|c|}
\hline Age & 0.236 & 0.038 \\
\hline Weight & 0.450 & 0.0001 \\
\hline Height & -0.151 & 0.131 \\
\hline BMI & 0.516 & 0.0001 \\
\hline Waist circumference & 0.359 & 0.003 \\
\hline SBP & 0.504 & 0.0001 \\
\hline DBP & 0.448 & 0.0001 \\
\hline MAP & 0.383 & 0.002 \\
\hline Glucose & 0.583 & 0.0001 \\
\hline HbA1c & 0.546 & 0.0001 \\
\hline Cholesterol & 0.437 & 0.0001 \\
\hline Triglyceride & 0.276 & 0.019 \\
\hline HDL-C & -0.102 & 0.226 \\
\hline LDL-C & 0.082 & 0.273 \\
\hline VLDL-C & 0.223 & 0.048 \\
\hline Insulin & 0.055 & 0.343 \\
\hline HOMA-IR & 0.436 & 0.0001 \\
\hline QUICKI & -0.528 & 0.0001 \\
\hline AST & 0.377 & 0.002 \\
\hline ALT & 0.366 & 0.003 \\
\hline ALP & 0.273 & 0.020 \\
\hline NO & 0.419 & 0.0001 \\
\hline MDA & 0.355 & 0.003 \\
\hline ADMA & 0.430 & 0.0001 \\
\hline DDAH & 0.385 & 0.002 \\
\hline Urea & 0.436 & 0.0001 \\
\hline Creatinine & 0.359 & 0.003 \\
\hline Uric acid & 0.359 & 0.003 \\
\hline eGFR & 0.368 & 0.002 \\
\hline ET-I & 0.567 & 0.0001 \\
\hline
\end{tabular}



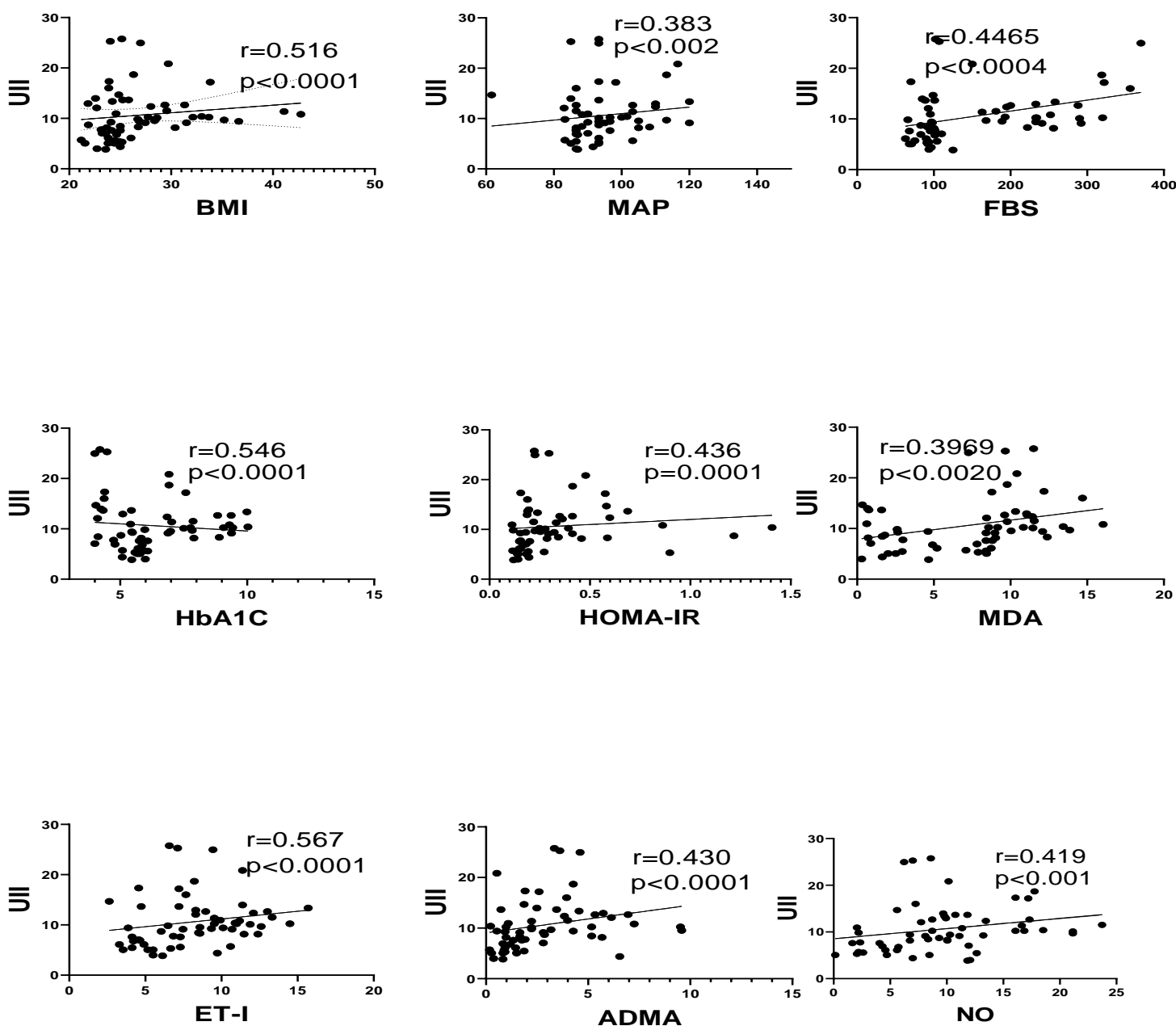

Figure 3-Correlations between UII and anthropometrics and clinical parameters.

Table 2- Stepwise multiple regression analysis of serum UII as a dependent variable to biochemical and vasoactive parameters

\begin{tabular}{|c|c|c|c|c|c|c|c|}
\hline Model & B & beta & Partial correlation & $\mathbf{R}^{2}$ Adj & ljusted $\mathbf{R}^{2}$ & $\mathbf{F}$ & $\mathbf{P}$ \\
\hline \multicolumn{8}{|l|}{1} \\
\hline Constant & 0.413 & & & 0.322 & 0.309 & 26.07 & 0.001 \\
\hline ET-I & 0.633 & 0.516 & 0.567 & & & \multicolumn{2}{|c|}{0.0001} \\
\hline 2 & & & & & & & \\
\hline Constant & 0.092 & & & 0.389 & 0.367 & 17.20 & 0.601 \\
\hline ET-I & 0.418 & 0.331 & 0.375 & & & & 0.006 \\
\hline HbA1C & 0.597 & 0.304 & 0.323 & & & & 0.018 \\
\hline
\end{tabular}

Table 3- Stepwise multiple regression analysis of serum UII as a dependent variable to anthropometric parameters

\begin{tabular}{|c|c|c|c|c|c|c|c|c|}
\hline \multirow{2}{*}{$\frac{\text { Model }}{1}$} & \multirow[t]{2}{*}{ B } & \multirow[t]{2}{*}{ beta } & Partial correlation & \multirow[t]{2}{*}{$\mathbf{R}^{2}$} & \multicolumn{2}{|c|}{ Adjusted R ${ }^{2}$} & \multirow[t]{2}{*}{$\mathbf{F}$} & \multirow[t]{2}{*}{$\mathbf{P}$} \\
\hline & & & & & & & & \\
\hline Constant & -0.804 & & & 0.266 & & & 20.33 & 0.053 \\
\hline $\begin{array}{l}\text { BMI } \\
2\end{array}$ & 1.255 & 0.516 & & 516 & & & & 0.0001 \\
\hline Constant & -3.470 & & & & 0.300 & 13. & & 0.009 \\
\hline BMI & 0.804 & 0.331 & 0.304 & & & & & 0.021 \\
\hline SBP & 1.583 & 0.304 & 0.281 & & & & & 0.034 \\
\hline
\end{tabular}




\section{Discussion}

Type 2 diabetes mellitus complications begin with the production of mitochondrial reactive oxygen species [26], which leads to lipid peroxidation with progression of endoplasmic reticulum (ER) stress and oxidative stress which further complicates diabetes disease [27, 28]. Many metabolic disorders, such as hyperglycemia, hyperinsulinemia, and hyperlipidemia, are known enhancers of ER stress along with the production of ROS by nicotinamide adenine dinucleotide phosphate (NADPH) oxidase and the increase of NO, MDA, and ADMA levels in the blood [29-33]. Mitochondrial ROS levels can be raised by the hexosamine pathway, increasing angiotensin-II, increasing advanced glycation end products (AGEs), polyol pathway flux, and increasing protein kinase $\mathrm{C}$ (PKC). All these pathways lead to damage of $\beta$-pancreatic cells [33].

Elevated serum UII levels increase UII receptor expression, which contributes to many metabolic pathophysiology conditions, including hypertension, heart failure, pulmonary hypertension, diabetes, and renal failure. UII level was reported to increase by twofold in subjects with T2DM without evidence of renal disease [34].

The details in Table- 1 show a significant correlation of UII with most of the anthropometric and biochemical parameters. UII was found in this study to be positively correlated with SBP and DBP as well as MAP, and this may be due to the association between UII and hypertension through the impairment of the endothelial layer. The vascular endothelial layer may be involved with the association between UII and hypertension [35]. The exact mechanism that leads to increasing hypertension is still not fully studied. Indeed, many studies suggested that UII increment increases nitric oxide secretion at early stages [36]. There were no significant correlations between the nondiabetic and diabetic groups in HDL-C, LDL-C, and insulin levels. The mechanisms underlying the increase of UII level with the changes in SBP and DBP are still not discovered totally, but previous studies on isolated aortic rings showed the vasoconstrictive effects of UII through stimulating a phospholipase C-dependent-inositol trisphosphate pathway [37-39]. $\mathrm{Ca}^{+}, \mathrm{PKC}$, extracellular signalregulated kinases (ERK), mitogen-activated protein kinases (MAPK), and Myosin Light Chain (MLC) have been proposed to be enrolled in human hUII-induced vasoconstriction. All these conclusions were proven by using inhibitors to confirm the exact pathways through which UII can conduct its various effects $[26,40]$. The activation and increase of Ras homolog family member A (RhoA) is another possible mechanism, where UII may activate it and increases calcium concentration inside the cells through opening voltage-gated calcium channels [41]. Waist circumferences, BMI, age, and weight are all correlated positively with UII, indicating a close relation between obesity, craving, and insulin imbalance with the progression of UII increase [42].

Insulin resistance factors, HOMA-IR, HbA1C, and FBG were all significantly increased and showed positive correlation with UII increase, while QUICKI-IS showed a high significant but negative correlation with UII $(r=-0.528 \mathrm{p}=0.0001)$. These results suggest UII tendencies to impair Bcell functions through fluctuations and disturbances of insulin regulation via the six pathways that were mentioned earlier in our discussion [43, 44].

Interestingly, UII showed a synergistically significant increase with the increase in ET-I levels, which is another potent vasoconstrictor that has a major role in diabetic complications. This increase of ET-I might be a consequence of co-effects with UII, resulting in acute endothelial injury and pathogenesis [37]. ADMA is an endogenous nitric oxide synthase (NOS) inhibitor (a dilatory gaseous molecule) that regulates and helps modulating NO and is increased significantly along with UII [45]. The level of DDAH, which is the enzyme responsible for the degradation of ADMA, was increased significantly in our results. Any increase of DDAH concentration in blood causes a decrease in ADMA levels consequently. However, this statement is controversy to our result, which might be due the decrease in renal clearance rates that might have ultimately affected the outcomes of the renal function tests in patients with T2DM in advanced stages, possibly caused by nephropathy and renal failure [46]. To confirm this, our data showed significant increases in the levels of renal function parameters (urea, creatinine, uric acid, and eGFR) along with significant correlations between the two groups [47]. Other diabetic complications include liver injury, fatty liver, and cirrhosis [48]. Meanwhile, levels of ALT, AST, and ALP are also correlated with UII positively in the present study. Fatty liver further increases blood glucose through the increase in the catabolism of branched chain amino acids that increases the glycation end products [36]. 
In this study, serum NO level was increased in diabetic subjects. This result is paradox to the physiological fact stating that when UII increases, NO should decrease. As the level of NO increases, the increase of the vasoconstrictor UII causes muscular contractions in various vascular beds, thus increasing NO release to remodel the vasculature. For that, we observed a high serum concentration of $\mathrm{NO}$ in diabetic group. The endothelial layer produces NO in response to UII but, however, this production and release decrease with aging [49]. This increase in NO is related to young-aged subjects and gradually decreases with aging when the muscles lose their elasticity and endothelial layer and become susceptible to vasoconstrictors like UII and ET-I.

Based on our case control study, as elucidated so far, the controversy shown in increasing the enzymatic activity of DDAH can be explained based on the notion that the increase of ROS and oxidative stress enhances the accumulation of ADMA by decreasing the catalytic effect of DDAH. This is confirmed by the increase in serum MDA level in our study. As another signaling pathway, the effective molecule of FoxO1 in endothelial cells leads to increase NOS and inhibit ADMA through the down-regulation of DDAH [50, 51]. Another possible pathway for the increase of serum DDAH levels may be the intake of metformin in patients with T2DM [52]. However, fibrates and statins (lipid lowering drugs) act through the improvement of the activity of DDAH in diabetes patients [53]. Metformin and ADMA are analogues that should exert the same molecular activity. However, according to our analysis, ADMA levels were still significantly high. The explanation of this result might be that the conditions inside the cell are less controlled in diabetic patients. Oxidative stress, poor antioxidant system, compromised immunity, and inflammations are all potential factors that could affect the proper functions of ADMA, while metformin is more stable and conducts its functions directly without interfering with factors inside the cell.

It is worthy to mention that the exact role of ET-I is exerted through the increase of UII levels, activating a variety of its own receptors and subtypes. The long lasting effects of these substances are thought to be through the continuous repetition of recurrent receptor activation without giving a chance to the cell to initiate its recovery.

\section{Conclusions}

The present study suggests that an increase of UII has a strong correlation to insulin-resistance and ET-I. Also, UII serum levels are correlated with weight and BMI. In addition, from our case control study, we can conclude that UII exerts its powerful effects through ET-I synergistically, and both together contribute to worsen the diabetic cases with age, along with with the increase of ADMA levels that inhibits NO and further strengthen the powerful effects of UII.

We recommend that trial studies are needed to figure out the role of UII antagonists, which could be a promising future therapy to prevent further progression of diabetic complications. Also, additional studies are needed to elucidate the roles of UII in the development of microangiopathies.

\section{References}

1. T. Fukui and Y. Takahashi. 2019. "[Bone fragility in type 1 diabetes and type 2 diabetes.]," (in jpn), Clin Calcium, 29(1): 51-56.

2. K. H. Park and W. J. Park. 2015."Endothelial Dysfunction: Clinical Implications in Cardiovascular Disease and Therapeutic Approaches," (in eng), J Korean Med Sci, 30(9): 121325.

3. B. Biadgo, T. Melak, S. Ambachew, H. W. Baynes, M. A. Limenih, K. N. Jaleta, B. Tachebele, M. Melku and M. Abebe. 2018. "The Prevalence of Metabolic Syndrome and Its Components among Type 2 Diabetes Mellitus Patients at a Tertiary Hospital, Northwest Ethiopia," (in eng), Ethiop J Health Sci, 28(5): 645-654.

4. D. Sun, Y. X. Cao, X. D. You, B. Y. Zhou, S. Li, Y. L. Guo, Y. Zhang, N. Q. Wu, C. G. Zhu, Y. Gao, Q. T. Dong, G. Liu, Q. Dong and J. J. Li. 2019. "Clinical and genetic characteristics of familial hypercholesterolemia patients with type 2 diabetes," (in eng), J Endocrinol Invest, 42(5): 591-598.

5. Z. Gao, M. Zuo, F. Han, X. Yuan, M. Sun, X. Li, R. Liu, W. Jiang, L. Zhang, B. Chang and J. Yang. 2019. "Renal impairment markers in type 2 diabetes patients with different types of hyperuricemia," (in eng), J Diabetes Investig, 10(1): 118-123.

6. A. S. E. Silva, F. V. Lacerda and M. P. G. da Mota. 2019. "Effect of Strength Training on Plasma Levels of Homocysteine in Patients with Type 2 Diabetes," (in eng), Int J Prev Med, 10: 80. 
7. H. Vargas-Uricoechea and M. F. Caceres-Acosta. 2019. "Blood pressure control and impact on cardiovascular events in patients with type 2 diabetes mellitus: A critical analysis of the literature," (in engspa), Clin Investig Arterioscler, 31(1): 31-47. Metas de control de la presion arterial e impacto sobre desenlaces cardiovasculares en pacientes con diabetes mellitus tipo 2: un analisis critico de la literatura.

8. A. Jia, W. Zeng, L. Yu, H. Zeng, Z. Lu and Y. Song. 2019. "Very low-density lipoprotein cholesterol is associated with extent and severity of coronary artery disease in patients with type 2 diabetes mellitus," (in eng), SAGE Open Med, 7, p. $2050312119871786,2019$.

9. A. Al-Salameh, P. Chanson, S. Bucher, V. Ringa and L. Becquemont. 2019."Cardiovascular Disease in Type 2 Diabetes: A Review of Sex-Related Differences in Predisposition and Prevention," (in eng), Mayo Clin Proc, 94(2): 287-308.

10. J. Pereira-Castro, C. Bras-Silva and A. P. Fontes-Sousa. 2019. "Novel insights into the role of urotensin II in cardiovascular disease," (in eng), Drug Discov Today, 24(11): 2170-2180.

11. J.-P. Segain, M. Rolli-Derkinderen, N. Gervois, D. Raingeard de la Blétière, G. Loirand and P. Pacaud. 2007. "Urotensin II is a New Chemotactic Factor for UT Receptor-Expressing Monocytes," The Journal of Immunology, 179(2): 901-909.

12. R. A. Silvestre, E. M. Egido, R. Hernandez and J. Marco. 2009. "Characterization of the insulinostatic effect of urotensin II: a study in the perfused rat pancreas," (in eng), Regul Pept, vol. 153(1-3): 37-42.

13. R. A. Silvestre, E. M. Egido, R. Hernandez, J. Leprince, D. Chatenet, H. Tollemer, N. Chartrel, H. Vaudry and J. Marco. 2004."Urotensin-II is present in pancreatic extracts and inhibits insulin release in the perfused rat pancreas," (in eng), Eur J Endocrinol, 151(6): 803-9.

14. R. Rahimi, J. Karimi, I. Khodadadi, H. Tayebinia, N. Kheiripour, M. Hashemnia and F. Goli. 2018. "Silymarin ameliorates expression of urotensin II (U-II) and its receptor (UTR) and attenuates toxic oxidative stress in the heart of rats with type 2 diabetes," (in eng), Biomed Pharmacother, 101: 244-250.

15. H. Peng, C. Li and C. Li. 2020. "New Biomarkers of Hypertension and Related Vascular Disorders," (in eng), Int J Hypertens, 2020: 5075242.

16. M. K. Deedi, A. M. Reddy and N. L. Kumar. 2017. "Role of Anthropometric Measurements in Development of CVD and Stroke among T2DM in East Godavari District, Andhra Pradesh, India," (in eng), J Clin Diagn Res, 11(7): Bc01-bc05.

17. M. U. Javaid, A. S. N. Isha, A. A. Sabir, Z. Ghazali and M. Nübling. 2018. "Does Psychosocial Work Environment Factors Predict Stress and Mean Arterial Pressure in the Malaysian Industry Workers?," (in eng), Biomed Res Int, 2018: 9563714.

18. A. S. Levey, J. Coresh, T. Greene, J. Marsh, L. A. Stevens, J. W. Kusek and F. Van Lente. 2007. "Expressing the Modification of Diet in Renal Disease Study equation for estimating glomerular filtration rate with standardized serum creatinine values," (in eng), Clin Chem, 53(4): 766-72.

19. S. Huey-Jen Hsu, M. F. Chen, D. R. Chen and T. C. Su. 2015. "Validation of the Estimation of Low-density Lipoprotein Cholesterol by the Modified Friedewald Equation in Ethnic Chinese Adults Living in Taiwan," (in eng), Intern Med, 54(18): 2291-7.

20. K. Eldin Ahmed Abdelsalam and M. E. A. Alobeid. 2017. "Influence of Grand Multiparity on the Levels of Insulin, Glucose and HOMA-IR in Comparison with Nulliparity and Primiparity," (in eng), Pak J Biol Sci, 20(1): 42-46.

21. G. E. Duncan, A. D. Hutson and P. W. Stacpoole. 2001. "QUICKI does not accurately reflect changes in insulin sensitivity with exercise training," (in eng), J Clin Endocrinol Metab, 86( 9): 4115-9.

22. W. Ratajczak-Wrona, E. Jablonska, B. Antonowicz, D. Dziemianczyk and S. Z. Grabowska. 2013."Levels of biological markers of nitric oxide in serum of patients with squamous cell carcinoma of the oral cavity," (in eng), Int J Oral Sci, 5(3): 141-5.

23. E. Jablonska, B. Kiersnowska-Rogowska, W. Ratajczak, F. Rogowski and J. Sawicka-Powierza. 2007. "Reactive oxygen and nitrogen species in the course of B-CLL," (in eng), Adv Med Sci, 52: 154-8.

24. I. M. M. Ali, J. H. Yenzeel and H. M. S. Al-ansari. 2020. "Evaluation of Oxidative Stress and LeptinLevel in Samples of Iraqi Obese Women," Iraqi Journal of Science, pp. 1565-1570. 
25. H. Xu, X. Du, J. Xu, Y. Zhang, Y. Tian, G. Liu, X. Wang, M. Ma, W. Du, Y. Liu, L. Dai, W. Huang, N. Tong, Y. Wei and X. Fu.2020. "Pancreatic $\beta$ cell microRNA-26a alleviates type 2 diabetes by improving peripheral insulin sensitivity and preserving $\beta$ cell function," (in eng), PLoS Biol, 18(2): e3000603, Feb 2020.

26. K. Tasaki, M. Hori, H. Ozaki, H. Karaki and I. Wakabayashi. 2004. "Mechanism of human urotensin II-induced contraction in rat aorta," Journal of pharmacological sciences, 94(4): 376383.

27. S. Rovira-Llopis, C. Bañuls, N. Diaz-Morales, A. Hernandez-Mijares, M. Rocha and V. M. Victor. 2017. "Mitochondrial dynamics in type 2 diabetes: Pathophysiological implications," (in eng), Redox Biol, 11: 637-645, Apr 2017.

28. C. Mozzini, U. Garbin, C. Stranieri, A. Pasini, E. Solani, I. A. Tinelli, L. Cominacini and A. M. Fratta Pasini. 2015. "Endoplasmic reticulum stress and Nrf2 repression in circulating cells of type 2 diabetic patients without the recommended glycemic goals," (in eng), Free Radic Res, 49(3): 244-52, Mar 2015.

29. S. Rajan, K. Shankar, M. Beg, S. Varshney, A. Gupta, A. Srivastava, D. Kumar, R. K. Mishra, Z. Hussain, J. R. Gayen and A. N. Gaikwad. 2016. "Chronic hyperinsulinemia reduces insulin sensitivity and metabolic functions of brown adipocyte," (in eng), J Endocrinol, 230(3): 275-90, Sep 2016.

30. E. Tampakakis, C. E. Tabit, M. Holbrook, E. A. Linder, B. D. Berk, A. A. Frame, R. BretonRomero, J. L. Fetterman, N. Gokce, J. A. Vita and N. M. Hamburg. 2016. "Intravenous Lipid Infusion Induces Endoplasmic Reticulum Stress in Endothelial Cells and Blood Mononuclear Cells of Healthy Adults," (in eng), J Am Heart Assoc, 5(1), Jan 112016.

31. S. H. Deo, N. T. Jenkins, J. Padilla, A. R. Parrish and P. J. Fadel. 2013. "Norepinephrine increases NADPH oxidase-derived superoxide in human peripheral blood mononuclear cells via alphaadrenergic receptors," (in eng), Am J Physiol Regul Integr Comp Physiol, 305(10): R1124-32, Nov 152013.

32. Z. Fiodorenko-Dumas, I. Dumas, K. Mastej and R. Adamiec. 2017. "Physical activity - related changes in ADMA and vWF levels in patients with type 2 diabetes: A preliminary study," (in eng), Adv Clin Exp Med, 26(4): 601-608, Jul 2017.

33. T. Ganz, J. Wainstein, S. Gilad, R. Limor, M. Boaz and N. Stern. 2017. "Serum asymmetric dimethylarginine and arginine levels predict microvascular and macrovascular complications in type 2 diabetes mellitus," (in eng), Diabetes Metab Res Rev, 33(2), Feb 2017.

34. K. L. Ong, L. Y. Wong and B. M. Cheung. 2008. "The role of urotensin II in the metabolic syndrome," (in eng), Peptides, 29(5): 859-67, May 2008.

35. H. Peng, M. Zhang, X. Cai, J. Olofindayo, A. Tan and Y. Zhang. 2013. "Association between human urotensin II and essential hypertension--a 1:1 matched case-control study," (in eng), PLoS One, 8(12): e81764, 2013.

36. D. M. Patel, M. Bose and M. E. Cooper. 2020."Glucose and Blood Pressure-Dependent PathwaysThe Progression of Diabetic Kidney Disease," (in eng), Int J Mol Sci, 21(6), Mar 232020.

37. H. Xie, X. Wang, Y. He, D. Huang, X. Qu, Y. Jiang, Y. An, S. Zhang and M. Zhang. 2020. "Association between Plasma Urotensin II and Risk of Hypertension: Findings from a Prospective Study," (in eng), Int J Hypertens, 2020: 3284769, 2020.

38. S. M. Garcia, L. M. Herbert, B. R. Walker, T. C. Resta and N. L. Jernigan. 2020. "Coupling of store-operated calcium entry to vasoconstriction is acid-sensing ion channel 1a dependent in pulmonary but not mesenteric arteries," (in eng), PLoS One, 15(7): e0236288, 2020.

39. L. Vuppaladhadiam, C. Ehsan, M. Akkati and A. Bhargava. 2020. "Corticotropin-Releasing Factor Family: A Stress Hormone-Receptor System's Emerging Role in Mediating Sex-Specific Signaling," (in eng), Cells, 9(4), Mar 312020.

40. M. Nishi, H. Tagawa, M. Ueno, S. Marumoto and T. Nagayama. 2020. "The urotensin II receptor antagonist DS37001789 ameliorates mortality in pressure-overload mice with heart failure," (in eng), Heliyon, 6(2): e03352, Feb 2020.

41. S. Y. Luo, S. Chen, Y. D. Qin and Z. W. Chen. 2016. "Urotensin- II Receptor Antagonist SB710411 Protects Rat Heart against Ischemia-Reperfusion Injury via RhoA/ROCK Pathway," (in eng), PLoS One, 11(1): e0146094, 2016. 
42. M. Calan, T. Arkan, T. Kume and F. Bayraktar. 2019. "The relationship between urotensin II and insulin resistance in women with gestational diabetes mellitus," (in eng), Hormones (Athens), 18(1): 91-97, Mar 2019.

43. O. Yilmaz, O. Calan, T. Kume and M. Calan. 2013. "The relationship of urotensin II with insulin resistance and hs-CRP in patients having PCOS," (in eng), Gynecol Endocrinol, 29(11): 970-3, Nov 2013.

44. K. M. Abbas, S. F. Alaaraji and R. S. Al-Shawk. 2020. "A Study of the Association Between IL17 and HOMA-IR in Iraqi Type 2 Diabetic Patients," Iraqi Journal of Science, pp. 491-498, 2020.

45. F. Mallamaci, S. Cutrupi, P. Pizzini, G. Tripepi and C. Zoccali. 2006."Urotensin II and Biomarkers of Endothelial Activation and Atherosclerosis in End-Stage Renal Disease*," American Journal of Hypertension, 19(5): 505-510, 2006.

46. J. Jacobi and P. S. Tsao. 2008. "Asymmetrical dimethylarginine in renal disease: limits of variation or variation limits? A systematic review," (in eng), Am J Nephrol, 28(2): 224-37, 2008.

47. H. J. Eyre, T. Speight, J. D. Glazier, D. M. Smith and N. Ashton. 2019. "Urotensin II in the development and progression of chronic kidney disease following $5 / 6$ nephrectomy in the rat," (in eng), Exp Physiol, 104(3): 421-433, Mar 2019.

48. M. Cigrovski Berkovic, L. Virovic-Jukic, I. Bilic-Curcic and A. Mrzljak. 2020. "Post-transplant diabetes mellitus and preexisting liver disease - a bidirectional relationship affecting treatment and management," (in eng), World J Gastroenterol, 26(21): 2740-2757, Jun 72020.

49. A. Ishihata, M. Sakai and Y. Katano. 2006. "Vascular contractile effect of urotensin II in young and aged rats: influence of aging and contribution of endothelial nitric oxide," (in eng), Peptides, 27(1): 80-6, Jan 2006.

50. A. J. Pope, L. Druhan, J. E. Guzman, S. P. Forbes, V. Murugesan, D. Lu, Y. Xia, L. G. Chicoine, N. L. Parinandi and A. J. Cardounel. 2007. "Role of DDAH-1 in lipid peroxidation productmediated inhibition of endothelial NO generation," (in eng), Am J Physiol Cell Physiol, 293(5): C1679-86, Nov 2007.

51. R. Menghini, V. Casagrande, M. Cardellini, M. Ballanti, F. Davato, I. Cardolini, R. Stoehr, M. Fabrizi, M. Morelli, L. Anemona, I. Bernges, E. Schwedhelm, A. Ippoliti, A. Mauriello, R. H. Boger and M. Federici. 2015. "FoxO1 regulates asymmetric dimethylarginine via downregulation of dimethylaminohydrolase 1 in human endothelial cells and subjects with atherosclerosis," (in eng), Atherosclerosis, 242(1): 230-5, Sep 2015.

52. G. Wojcicka, A. Jamroz-Wisniewska, G. Czechowska, A. Korolczuk, S. Marciniak and J. Beltowski. 2016. "The paraoxonase 1 (PON1), platelet-activating factor acetylohydrolase (PAF$\mathrm{AH})$ and dimethylarginine dimethylaminohydrolase (DDAH) activity in the metformin treated normal and diabetic rats," (in eng), Eur J Pharmacol, 789: 187-194, Oct 152016.

53. Y. M. Magdy, O. A. El-Kharashi, D. A. A. El-Waseef, E. S. Nabih and A. A. Abd El Samad. 2018."Insights into hepatic and renal FXR/DDAH-1/eNOS pathway and its role in the potential benefit of rosuvastatin and silymarin in hepatic nephropathy," (in eng), Exp Mol Pathol, 105(3): 293-310, Dec 2018. 